\title{
永久磁石とボールベアリングを用いた教育用せん断振動模型の開発 DEVELOPMENT OF SHEAR VIBRATION MODEL FOR EDUCATION USING PERMANENT MAGNETS AND BALL BEARINGS
}

\author{
江 原夏季*1, 平井 敬*2, 福和伸夫*3 \\ Natsuki EHARA, Takashi HIRAI and Nobuo FUKUWA
}

\begin{abstract}
A new shear vibration model for architectural education using permanent magnets and ball bearings was developed. In the model the restoring force is generated by magnetic interactions, causing long natural period and stable performance comparing to existing models. Additionally, the model has a lot of features: inexpensiveness of materials, variable natural period, visible shear wave propagation, multiple applications to represent soil and building structures, and so on. In this paper, basic characteristics of the model are revealed by analyses and experiments.
\end{abstract}

Keywords : Shear vibration model, Education for building vibration, Disaster prevention, Permanent magnet, Ball bearing, Vibration experiment せん断振動模型, 振動論教材, 防苂啓発, 永久磁石, ボールベアリング, 振動実験

\section{1. はじめに}

工学教育においては，机上の学習だけでは興味を持ちづらい，実 現象と結びつかず知識が身につかないといった課題がある。 その解 決策として, 建築構造力学の分野では, 身の周りにある材料を学習 の補助教材として用いた模型教材 ${ }^{1)}$, 2)が開発されており, 模型教材 の利用後に行ったアンケートの結果から好意的な効果が報告されて いる. 他にも，コンピュータを用いた補助教材ソフトウェア ${ }^{3)}$, 4)も 開発されている.

耐震工学の分野においても, 構造物や地盤の振動・波動現象は時 間や振動数の概念が伴う複雑な現象であり, やはり同様の課題を抱 えている. 地震多発国である日本で建築分野を学ぶ学生にとって, 構造系専攻でなくとも振動・波動現象の本質を理解することは必要 であり，建築に関わる技術者・実務者もまた然りである.

このような背景があり, 著者等はまず振動論教育の補助教材とし て「手回しぶるる」5)を開発した.これは, 手動の振動台と複数の鉄 製建物模型がセットとなっている可搬型の教材であり，好評のため 国内外で 100 台以上が流通した. 他にも, 振動実験教材が多数開発 され 6), 7)，8，よりわかりやすく振動現象を教えるための試行錯誤が なされてきた. 既往の振動実験教材も十分に学習効果が見込めるも のであるが, 振動現象の見や寸さの観点からさらなる改善の必要性 があった。 そのため, 本論文では誰もが手に入れられる材料で構成 され, 波動の伝播も含めて立体的なせん断振動を表現可能であり,
かつ既往の模型よりも多様な建物・地盤の振動性状を表せる模型を 新たに開発した.

Fig. 1 に, 本研究で開発した模型の例を示す. 開発した模型は, 永 久磁石とボールベアリングを用いた全く新しいアイデアによるせん 断振動模型である. (a) は深さの変化する不整形地盤, (b) は高層建 物, (c) は免震建物の模型であるが，いずれも同じ部材要素から組み 立てられている，その構成は，四隅に磁石を接着した板を，鉄球を 介して柱状に積み上げていくもので，地盤の場合には水平ばねで土 柱間を接続するというものである，層間変位を与えたときに，磁気 力により復元力が生じるしくみである，机上で実験が行える程度の 大きさであり，振動実験を伴う学習が容易に実施可能である．磁石 の接着方法や鉄球の大きさを変えることで，剛性・高さの調整が容 易であり, 複数回利用しても劣化による剛性低下等が起こらない. 加えて, 連続体を模した模型も作成できるため, せん断波の伝播の 様子も目視によって理解することが可能である.

本論文では実験と解析の両面からこの新しい模型の基本的な復元 力特性や動特性について検討寸る，第 2 章では，開発した模型の概 要について紹介寸る. 第 3 章では, 本模型の単層のみの静的復元力 特性について, 有限要素法を用いた磁場解析と静的せん断載荷実験 により検討する．第 4 章では，模型振動台実験により，単層模型の 動特性について評価する，第 5 章では，多層の模型内を伝わるせん 断波の伝播性状を分析する.

\footnotetext{
*1 名古屋大学大学院環境学研究科 大学院生

*2 名古屋大学大学院環境学研究科 助教・博士 (工学)

Grad. Student, Grad. School of Environmental Studies, Nagoya Univ.

*3 名古屋大学減災連携研究センター 教授·工博 


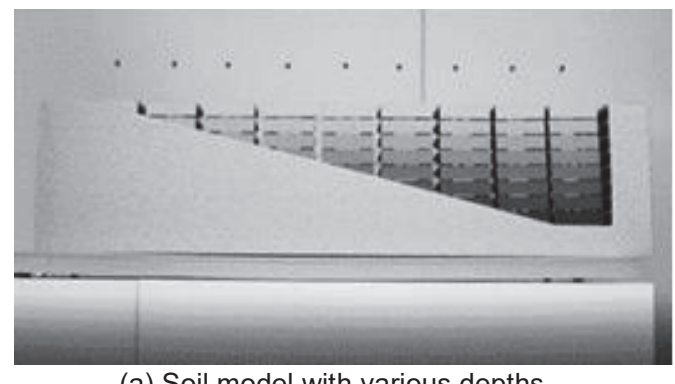

(a) Soil model with various depths

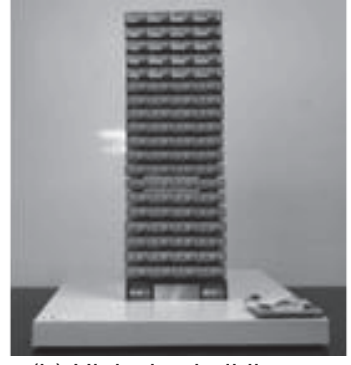

(b) High-rise building

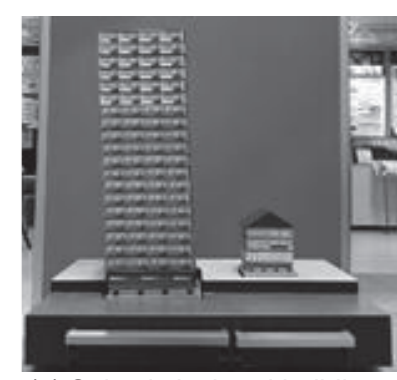

(c) Seismic isolated buildings

Fig. 1 Applications of developed shear vibration model

なお，本論文は文献 9)を発展させたものであることを付記する，

\section{2. せん断振動模型の概要}

Fig. 2 に, 開発したせん断振動模型のしくみを示す. 模型は四隅に 短い円柱状の永久磁石を接着した板をボールベアリングを介して積 み上げることで構成される. Fig. 1 に示した模型の内部もすべて同 様の部分で構成でされている. Fig. 2 (a)は板の両面に磁石を配置し た Type Aの 3 層模型, Fig. 2 (b)は片面に磁石を配置した Type B の 2 層模型であり, Fig. 2 (c) は復元力が生じるしくみを示している. Fig. 2 (c) に示す通り, ベアリングが鉛直力を支持し, 層間変位 $\delta$ が生 じると磁石間に働く磁気力の水平分力 $f$ が生じる. 層間に存在する 磁石組すべての $f$ の総和が復元力 $F$ として働く.

本模型は，ベアリングを挟んだ上下間の磁石間の距離を変える （Type A と Type B のように磁石の貼り付け方を変える，またはべ アリングの直径を変える), または接着寸る磁石の数を変えることで 層間の剛性を調整することができる.さらに，板の積み上げる数を 増やすことで模型の高さを容易に変えることが可能である．また， 復元力がばねなどの機械的な部品ではなく磁力によって生じるため, 繰り返し実験を行っても劣化による剛性の低下が生じない利点があ る.

\section{3. 単層模型の静的復元力特性}

層間変位に対する復元力の特性は, ベアリングの材質や直径, 磁 石の配置方法（Type A と Type B) によって変化する. 本章では, 有 限要素法を用いた磁場解析 $\left.{ }^{10}\right)$ と静的せん断載荷実験により, 模型の 各パラメータを変えたときの単層模型の静的復元力特性への影響を 明らかにする。

\section{1. 電磁気学的考察に基づく予備検討}

本模型では, 磁石間に作用する磁気力を復元力として利用するた め, 電磁気学に基づいて復元力特性を予測することができる.特に, ベアリングの透磁率が真空に等しい場合には, 磁場の変形を考慮す る必要がないため, 定式化が容易である. まず, 復元力特性の傾向 を把握するために, この条件において予備的に検討を行う。これは ベアリングとして木球やプラスチック球を用いた場合に相当する. 一方, ベアリングとして鉄球を用いた場合には, 磁場が鉄球内に集 中寸る形で複雑に変形するため, その解析は有限要素法に頼らざる を得ない。これについては, 次節以降で詳述する.

Fig. 3 のように, ベアリングを介して一対の磁石が向かい合う状 態を考える. 磁石 A は空間に固定されており, 磁石 B は水平方向に

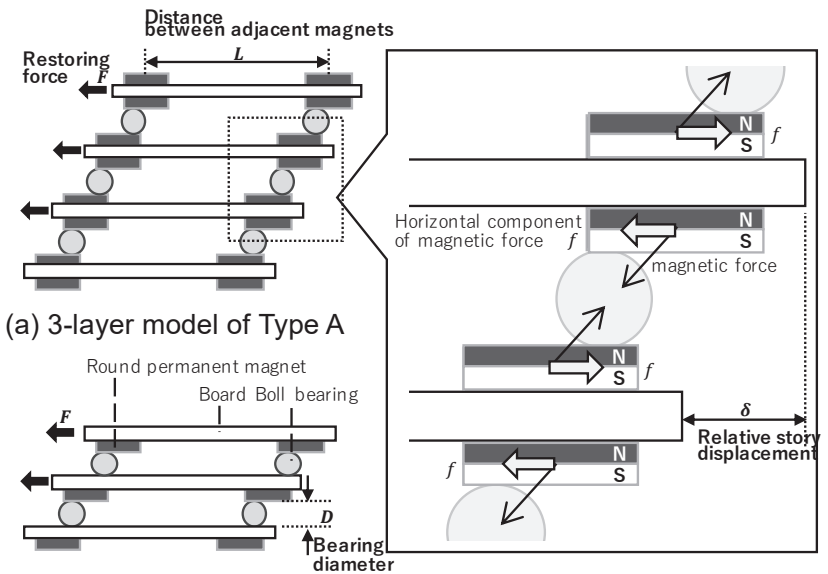

b) 2-layer model of Type B

(c) Mechanism of the restoring force

Fig. 2 Illustrations of shear vibration model

のみ移動可能とする. 磁石 A が作る任意の位置 $\boldsymbol{x}$ における磁場べク トル $\boldsymbol{H}(\boldsymbol{x})$ は次式で表される.

$$
\boldsymbol{H}(\boldsymbol{x})=-\nabla \int_{V_{\mathrm{A}}} \phi(\boldsymbol{x}, \boldsymbol{\xi}) d V
$$

ここで, 積分範囲 $V_{\mathrm{A}}$ は磁石 $\mathrm{A}$ 全体とする. $\phi(x, \boldsymbol{\xi})$ は磁石 $\mathrm{A}$ 内の位 置 $\boldsymbol{\xi}$ の微小部分によって $\boldsymbol{x}$ に生じる磁位（単位磁荷あたりのポテン シャルエネルギー）であり，次式で与えられる。

$$
\phi(x, \boldsymbol{\xi})=\frac{1}{4 \pi \mu_{0}} \frac{\boldsymbol{m} \cdot(\boldsymbol{x}-\boldsymbol{\xi})}{|\boldsymbol{x}-\boldsymbol{\xi}|^{3}}
$$

ここで， $\mu_{0}$ は真空の透磁率， $\boldsymbol{m}$ は磁石の強さを表す磁気双極子モー メント密度（表面磁束密度に等しい）である，層間変位 $\delta$ のきに 磁石 $\mathrm{B}$ が占める空閒を $V_{\mathrm{B}}(\delta)$ とすると, 磁石 $\mathrm{B}$ が持つ全ポテンシ ヤルエネルギー $U(\delta)$ は以下のように表される.

$$
U(\delta)=-\int_{V_{\mathrm{B}}(\delta)} \boldsymbol{m} \cdot \boldsymbol{H}(\boldsymbol{\xi}) d V
$$

ポテンシャルエネルギーの勾配が磁石 B に作用寸る磁気力となるの で，その $x$ 方向分力 $f(\delta)$ は次式となる.

$$
f(\delta)=-\frac{\partial U(\delta)}{\partial x}
$$

Fig. 4 (a) に式 (1) の磁場分布，(b) に式 (3) のポテンシャル曲線, (c) に式 (4) の磁気力の $x$ 方向分力を規格化した状態で示寸. 磁石 の半径を $r=9 \mathrm{~mm}$ として, 磁石の厚さ $b=4.5 \mathrm{~mm}$, 磁石間距離 $h=$ $14.5 \mathrm{~mm}$, 磁気双極子モーメント密度の向きは $z$ 方向, 大きさは $m$ で 一様とした. 磁場の分布は $x$ 軸と $z$ 軸に対して対称となるため、 $x>$ 0 かつ $z>0$ の範囲のみ示した. 


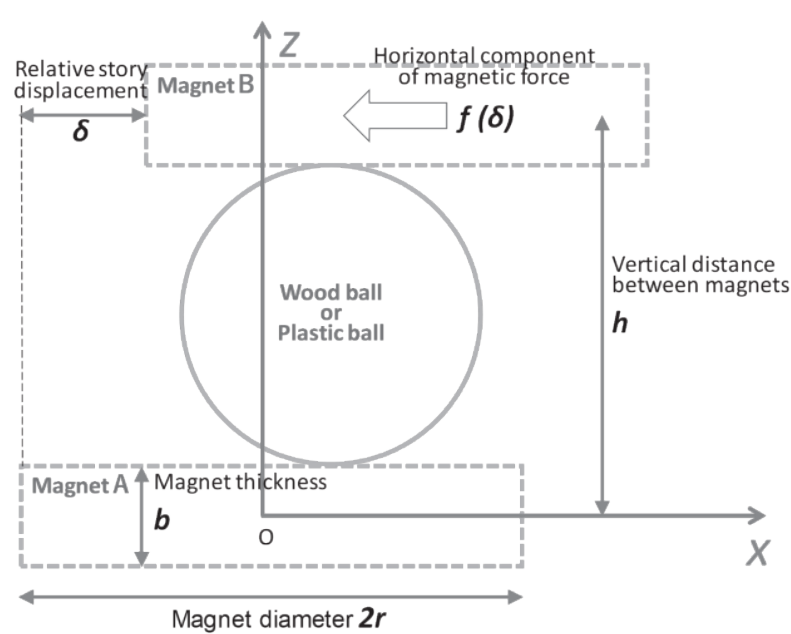

Fig. 3 Illustrations of analysis model

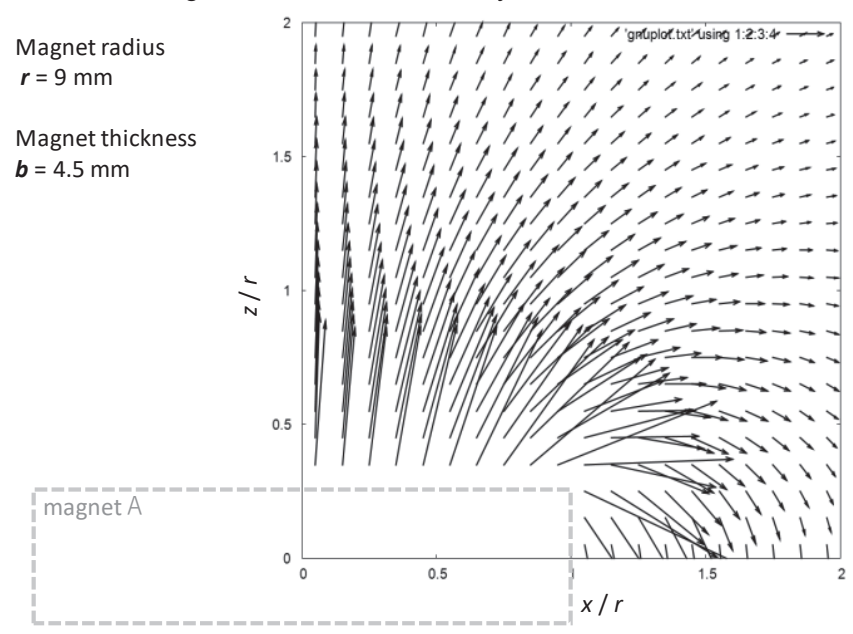

(a) Magnetic field outside magnet $\mathrm{A}$

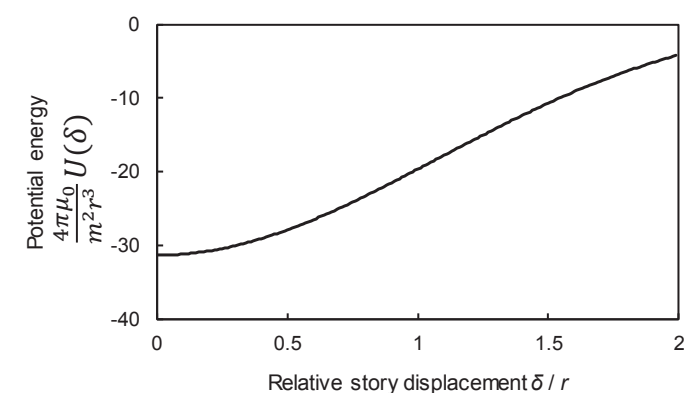

(b) Magnetic potential

against relative story displacement

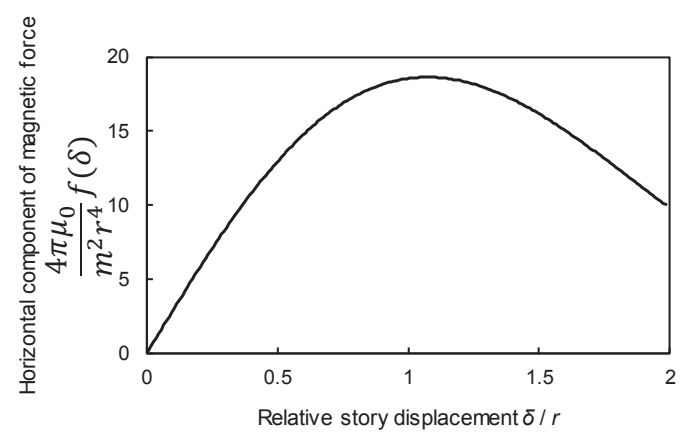

(c) Horizontal component of magnetic force against relative story displacement

Fig. 4 Theoretical analysis for magnetic force

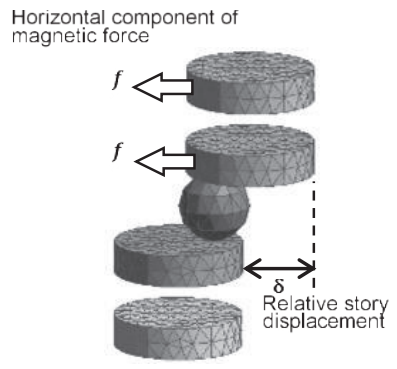

(a) Model of Type A

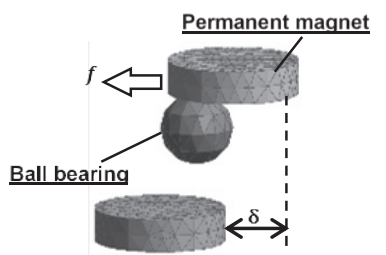

(b) Model of Type B
Fig. 5 Finite element analysis model of a set of magnets

Fig. 4 (a) より, 磁石 A からの距離とともに磁場の強さが急激に減 少することがわかる. Fig. 4 (b)，(c) より，ポテンシャル曲線は層間 変位が小さい範囲では下に凸の 2 次関数に近い形状であり, それに 対応して磁気力の $x$ 方向分力, 寸なわち復元力特性はほぼ直線とな ることがわかる，層間変位がより大きくなるとポテンシャル曲線は 0 に漸近するが, これは無限遠方で磁場の強さが 0 となるため当然 である．復元力特性もこれを反映して徐々に傾きが減少し，おおむ ね $\delta / r>1.1$ では負勾配に転ずる。このように本模型の復元力特性は 実在の建物に近いソフトニング型の傾向を示すことが予想される.

\section{2. 有限要素法による磁場解析と静的せん断載荷実験}

Fig. 5 に, 磁場解析に用いる有限要素モデルを示す. (a)は Type A, (b)は Type B のベアリングを介した上下の 1 組の磁石（以下，「1 組 の磁石」と称する）を示している．解析にはムラタソフトウェア株

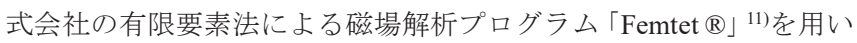
た。本模型で用いる板の材料は木またはアクリルとしているが，こ れらの物質は透磁率が小さく, 磁場の分布にほとんど影響を与えな い，そのため，磁場解析にあたって磁石とベアリングのみが空間に 固定されている状態をモデル化した. 実験等で実際に用いる直径 18 $\mathrm{mm}$, 厚み $4.5 \mathrm{~mm}$ の異方性フェライト磁石を対象に, モデルのメッ シュのサイズは約 $2 \mathrm{~mm}$ とした．磁石の強さを表す残留磁束密度は $400 \mathrm{mT}$ とした，層間変位 $\delta$ をパラメータとして上側の磁石に生じる 磁気力の水平成分 $f$ の総和 $F$ を算出し, 復元力特性を評価した.

Fig. 6 (a)に, 単層模型のせん断載荷実験の概要を示す. 模型の下 側の板を机上に固定し，上側の板を小型振動台 ${ }^{8)}$ の側面を用いて横 方向に変位速度 $1 \mathrm{~mm} / \mathrm{s}$ で準静的に単調載荷した. その際, 振動台と 板の間に設置した小型ロードセルにより載荷せん断力を，振動台の 側面に設置した接触型変位計により模型の層間変位を, それぞれ少 ンプリング周波数 $200 \mathrm{~Hz}$ で計測した．Fig. 6 (b)に，試験体の一例の 写真を示す. 試験に用いた板は $100 \times 100 \mathrm{~mm}$, 厚み $6 \mathrm{~mm}$ の木板と し，隣り合う磁石の中心間距離は $L=70 \mathrm{~mm}$ とした.

\section{3. 隣り合う磁石の距離が復元力特性に与える影響}

本模型は板の四隅に磁石を設置しているため, 隣り合う磁石どう しが互いの磁界の形を変形させ，復元力特性に影響を与える可能性 がある. 準備として, 隣り合う磁石の中心間距離 $L$ が復元力特性に 及ぼす影響について解析により検討を行う.

Fig. 7 に, 隣り合う磁石の中心間距離 $L$ をパラメータとした復元 力特性の解析結果を示寸. 中心間距離 $L=20 \mathrm{~mm}, 50 \mathrm{~mm}, 70 \mathrm{~mm}, \infty$ 


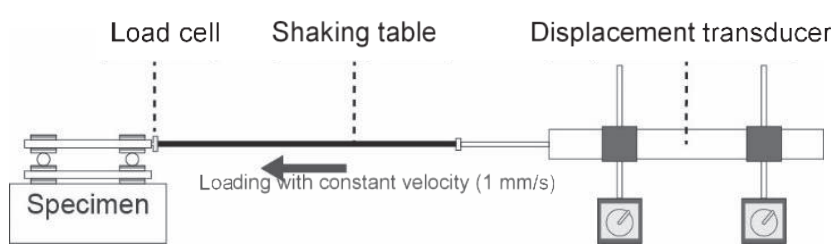

(a) Illustration of experiment

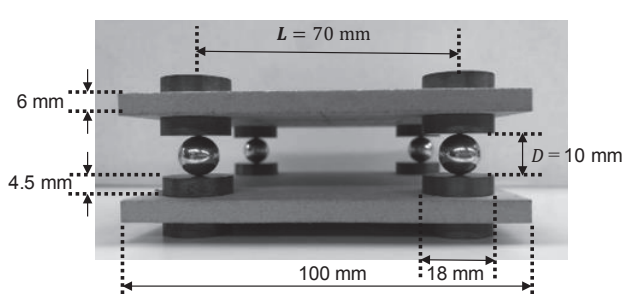

(b) photo of a specimen

Fig. 6 Shear loading test

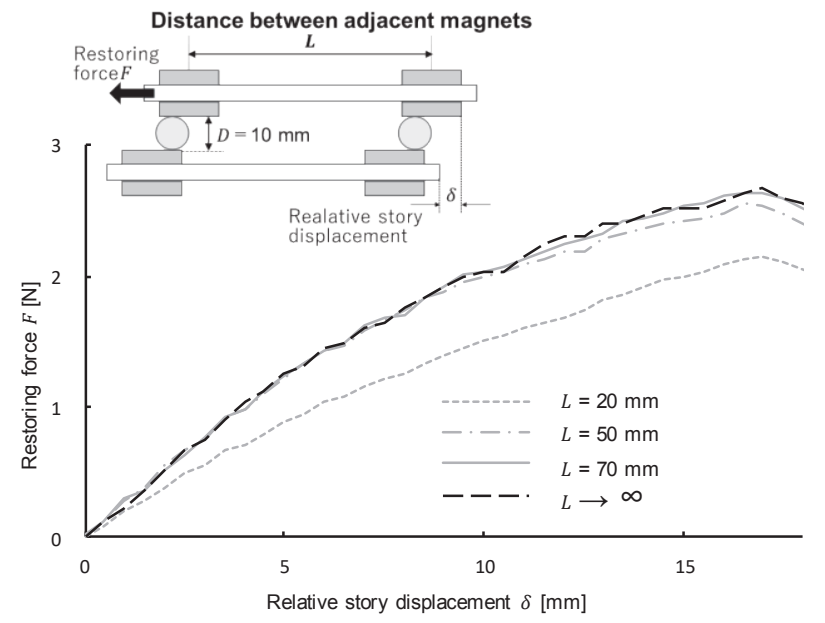

Fig. 7 Theoretical restoring force characteristics against distance between adjacent magnets

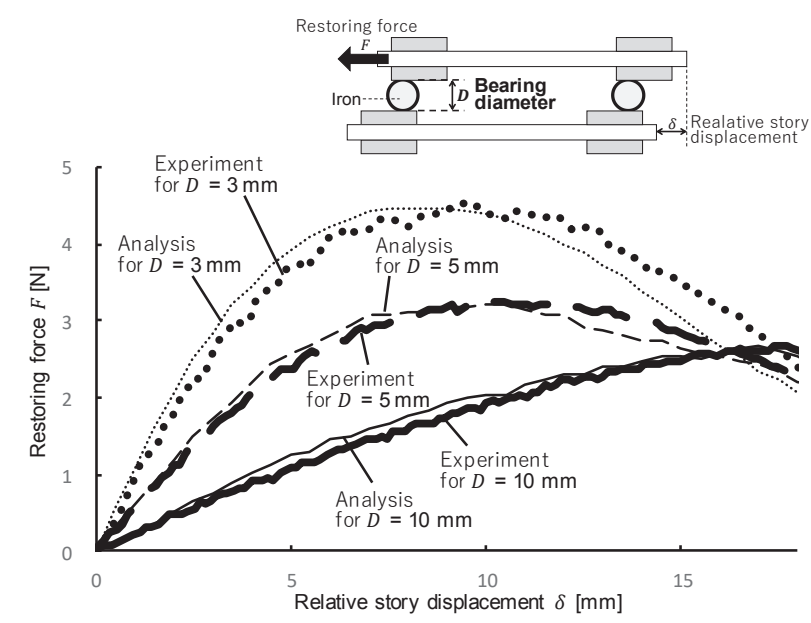

Fig. 8 Restoring force characteristics for various bearing diameters for Type A

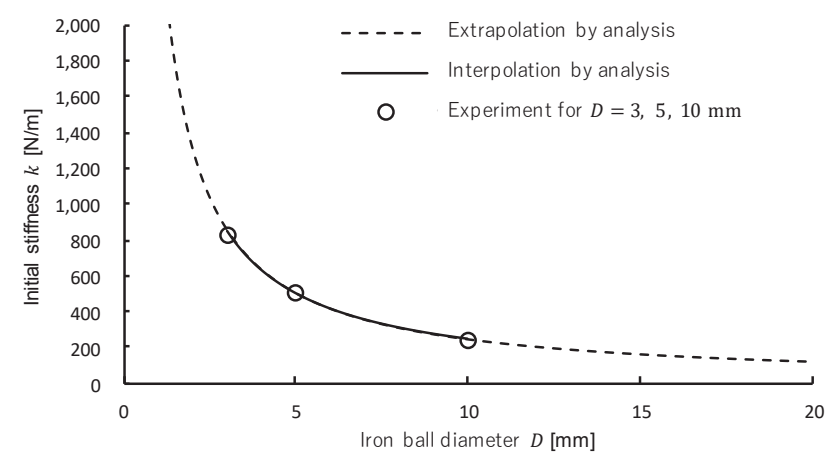

Fig. 9 Effect of iron ball diameter on stiffness

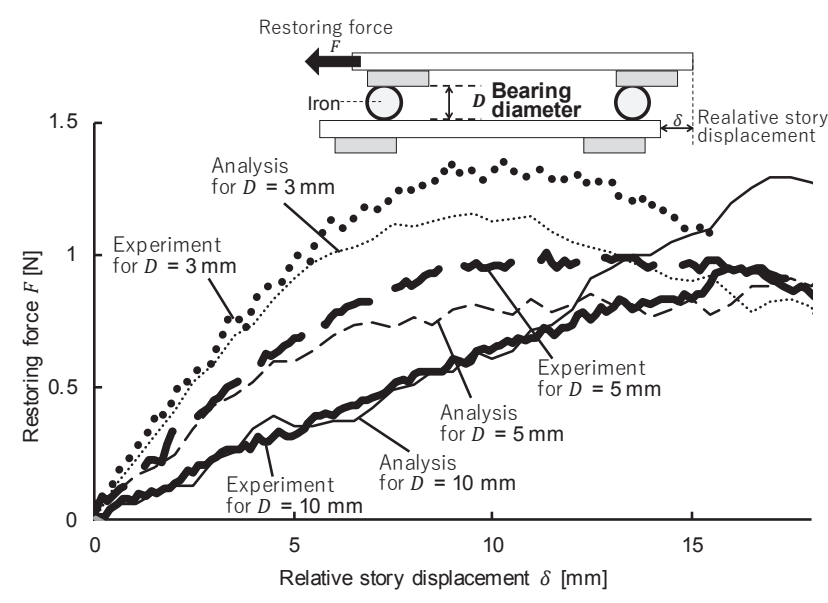

Fig. 10 Restoring force characteristics for various bearing diameters for Type B

の 4 組の磁石をモデル化した．ただし， $L \rightarrow \infty$ の場合については, 1 組の磁石のみをモデル化することで隣の磁石組との相互作用がな い状態を表現し，これによる復元力を 4 倍した值を用いた. Fig. 7 よ り，磁石の中心間距離 $L$ の増大とともに $L \rightarrow \infty$ の結果に漸近して いることがわかる．特に， $L=70 \mathrm{~mm}$ の結果は $L \rightarrow \infty$ の結果とほぼ 一致している．以降の検討では、すべて隣り合う磁石の中心間距離 を $L=70 \mathrm{~mm}$ として、磁場解析を行う際には、一組の磁石による復 元力の計算值を 4 倍して考えることとする.

\section{3． 4. ベアリングの直径と材質, 磁石の配置方法の影響}

Fig. 8 に, Type A の試験体について, ベアリングの直径による静 的復元力特性の変化を示す. Fig. 8 より, 3 種類のベアリングの直径 による復元力特性の実験結果と解析結果がよく一致していることが わかる.さらに, 解析により求めたベアリングの直径と初期剛性の 関係を Fig. 9 に示す。層間変位 $3 \mathrm{~mm}$ での割線剛性をもって初期剛 性とみなし, ベアリングの直径 $3 \mathrm{~mm}$ 末満および $10 \mathrm{~mm}$ を超える範 囲は外挿として破線で表した. Fig. 9 より , ベアリングの径を大きく すると初期剛性を小さくすることが可能であることがわかる。これ は, ベアリングの直径とともに上下の磁石間距離が増大し, 生じる 磁気力が小さくなるためである. また, $D=10 \mathrm{~mm}$ の復元力特性で あれば層間変位が約 $15 \mathrm{~mm}$ 以下 の範囲で, $D=5,3 \mathrm{~mm}$ の復元力特 性であれば層間変位が約 $7 \mathrm{~mm}$ 以下の範囲でほぼ線形の復元力特性 が再現可能であることがわかる.

Fig. 10 に, Type B の試験体について, ベアリングの直径による静 的復元力特性の変化を示す. 同じ直径のベアリングを用いた Type A の結果に比べ, Type B の方が初期剛性が小さいことがわかる.木板 の厚み分だけベアリングを介した磁石間の距離が増加することや, 


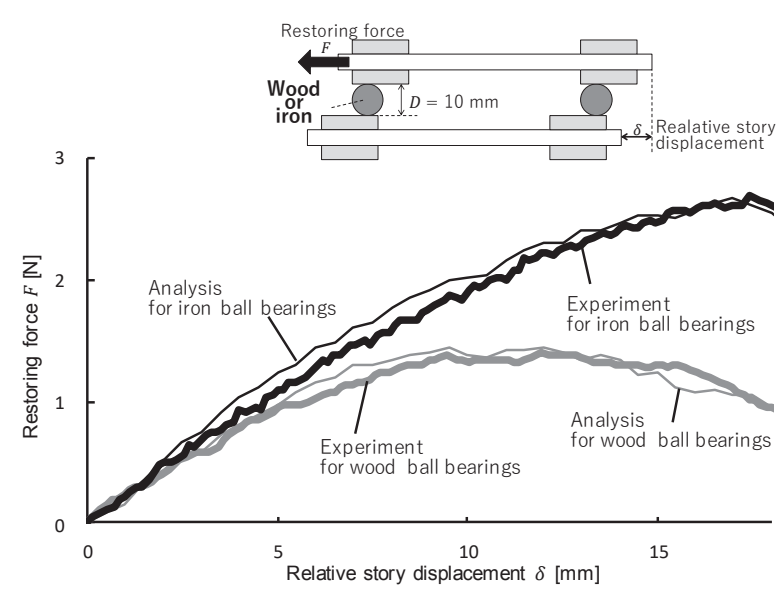

Fig. 11 Restoring force characteristics for iron and wood ball bearings

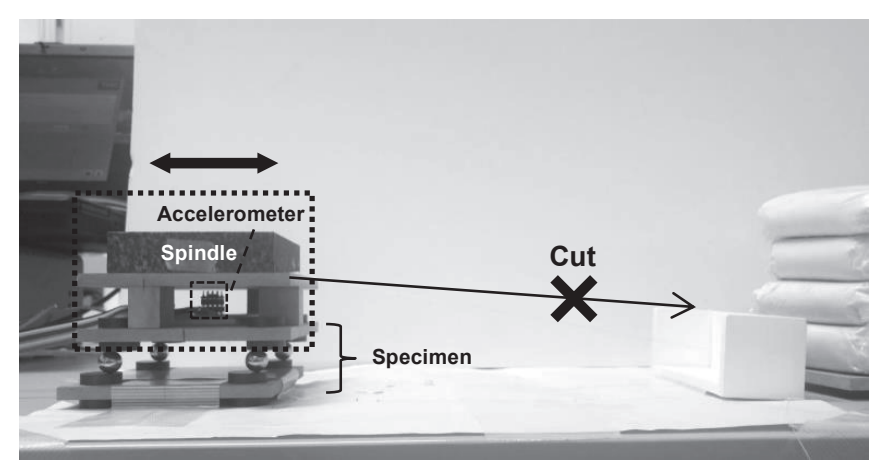

(a) Experiment and measurement system

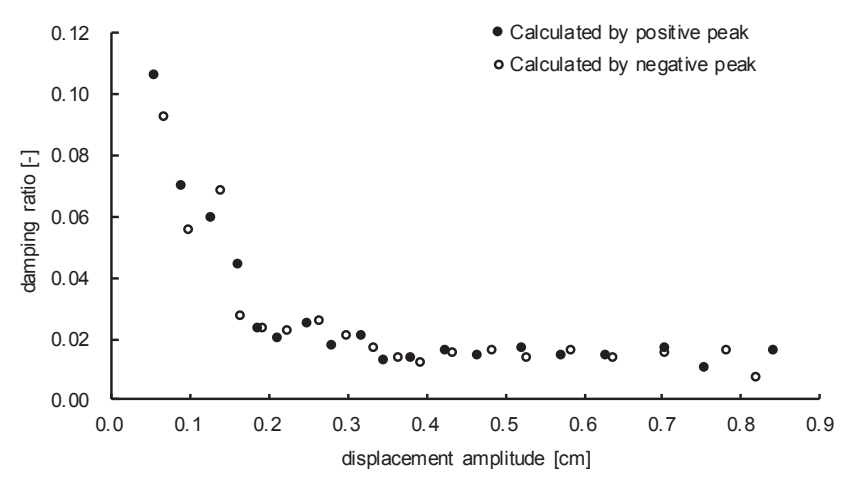

(c) Damping ratio against displacement amplitude

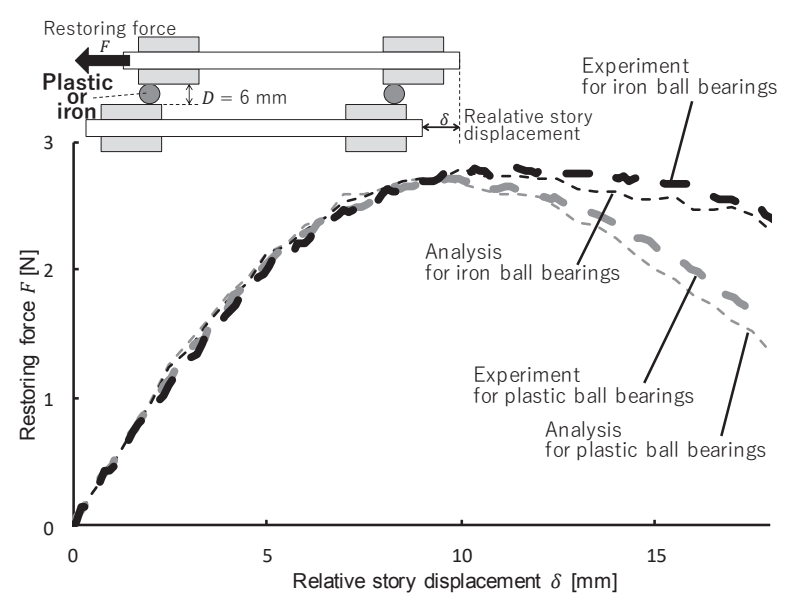

Fig. 12 Restoring force characteristics for iron and plastic ball bearings

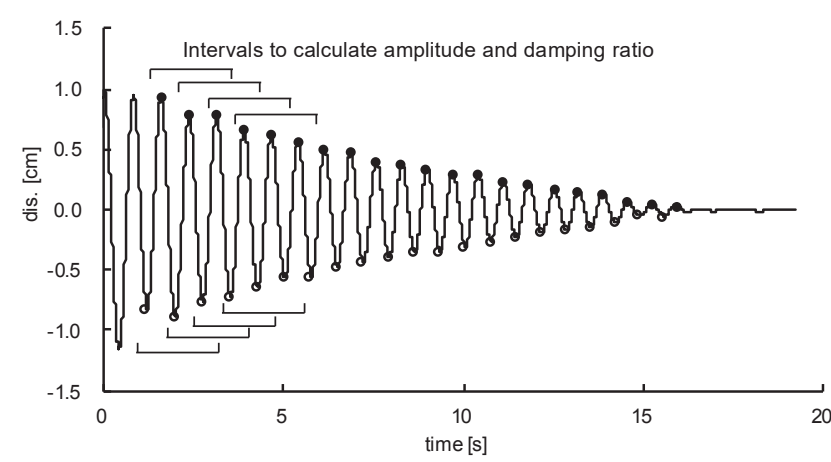

(b) Displacement time series of free vibration

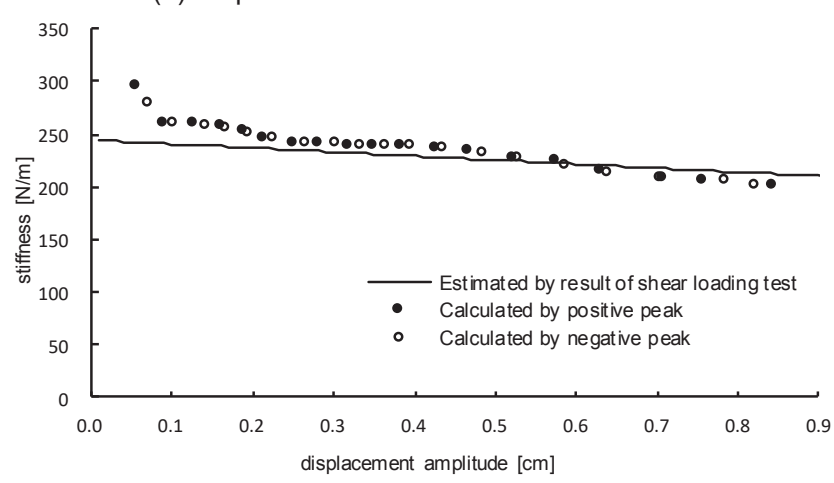

(d) Stiffness against displacement amplitude

Fig. 13 Free vibration test to investigate the effect of amplitude on dynamic characteristics

上側の板に設置された磁石の数が減ることにより（Type A では板を 挟んで 2 枚の磁石が存在するのに対し, Type B では 1 枚のみであ る), 生じる磁気力の総和が小さくなるためである.

Fig. 11 と Fig. 12 に, Type A の試験体について, ベアリング材料 による静的復元力特性の変化を示寸. Fig. 11 は直径 $D=10 \mathrm{~mm}$ の鉄 球と木球の比較, Fig. 12 は $D=6 \mathrm{~mm}$ の鉄球とプラスチック球の比 較である. 木球やプラスチック球よりも鉄球を用いた方が勒性のあ る復元力特性を示している. これは, 木球やプラスチック球を用い た場合には上下の磁石どうしに引力が生じるのみであるのに対し, 強磁性体である鉄球を用いた場合には, 鉄球が磁化することによっ て鉄球と磁石との間にも引力を生じるためである.

以上の結果より, ベアリングの材質や直径, 磁石の配置方法 (Type
A と Type B）による層間の復元力特性の違いが明らかになった. 建 物や地盤の模型を構築した際にも剛性を調整することができるため, 教育用振動模型として活用しや寸い. なお, ベアリングとしては, 大きな勒性能があり再現可能な変形が大きくなること, 崩壊した際 に磁石に吸着して模型部品がばらばらになりにくく扱いやすいこと, 容易に入手できることから，鉄球が優れていると考えている.

また, Fig. 8〜12より実験結果と解析結果がよく一致しており, 本模型は建物に近いソフトニング型の復元力特性となるという予想 が確認できた.

\section{4. 单層模型の動特性}

本模型は振動論の教材としての使用を念頭に置いているため, 固 


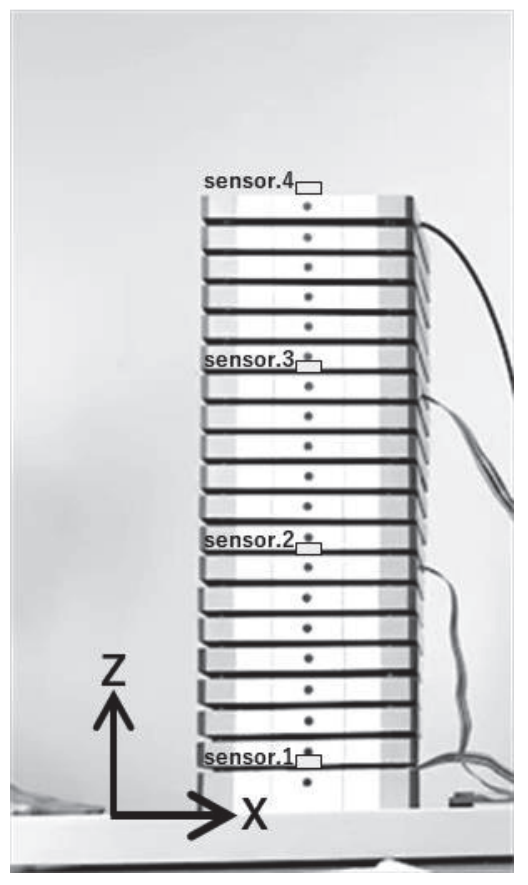

(a) 19-layer model

and measurement system

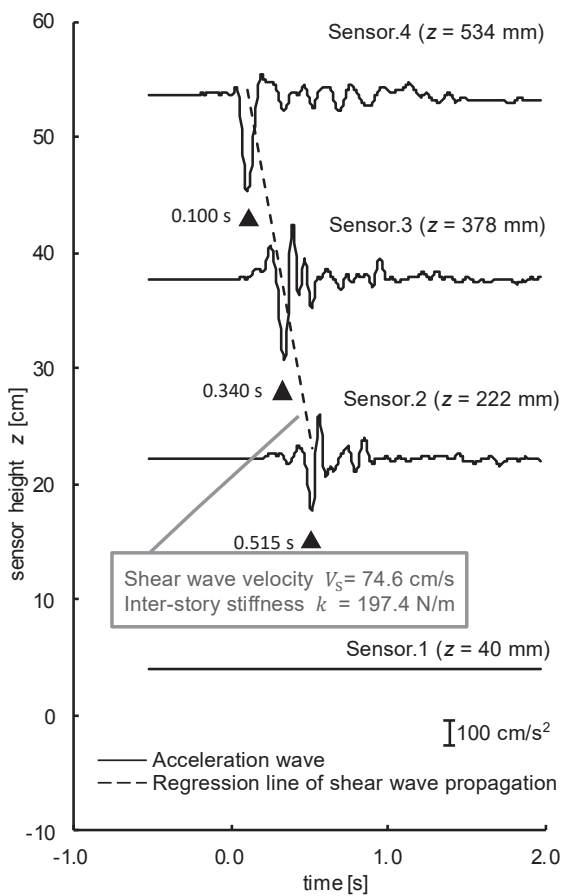

(b) Acceleration

by impulse excitation at the top

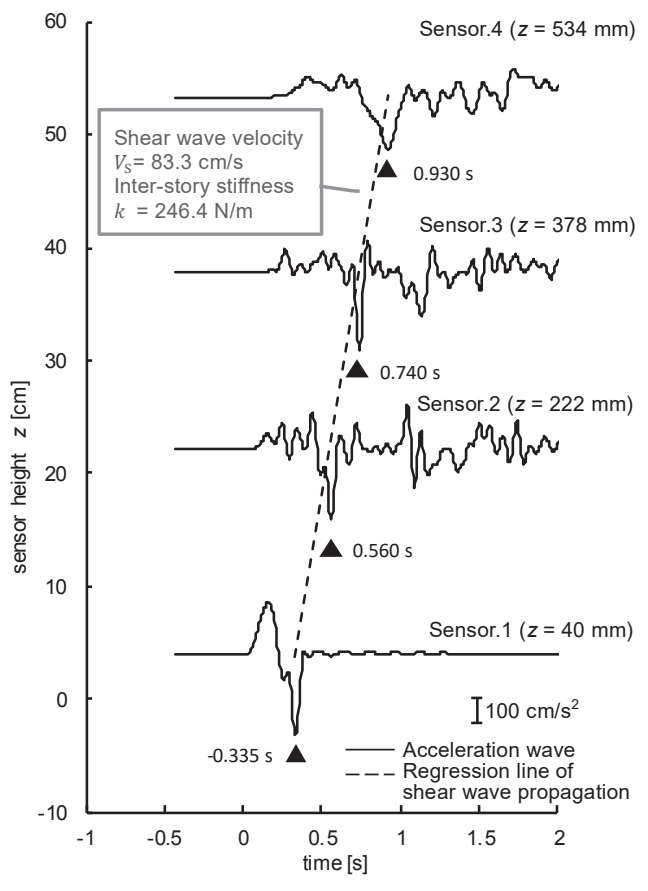

(c) Acceleration

by step excitation at the bottom

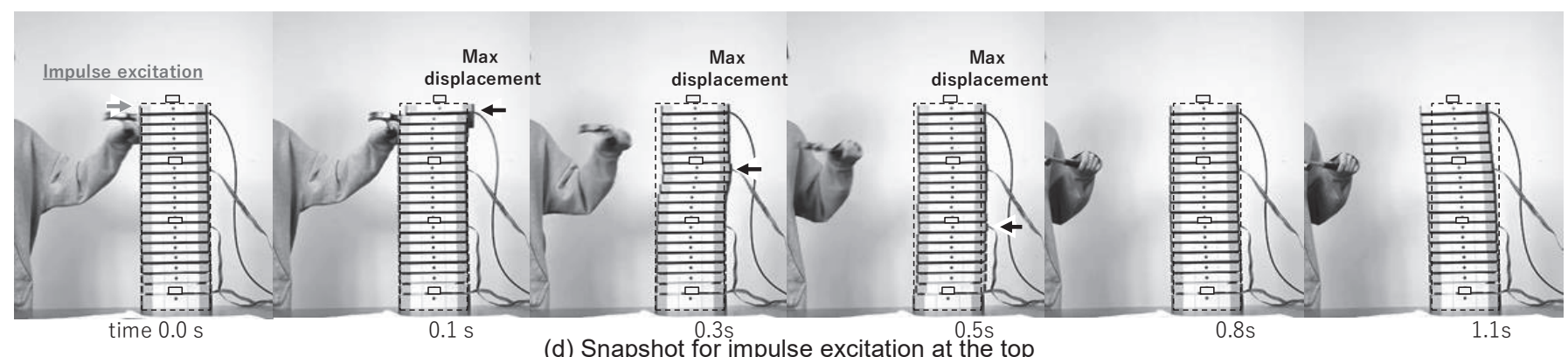

(d) Snapshot for impulse excitation at the top

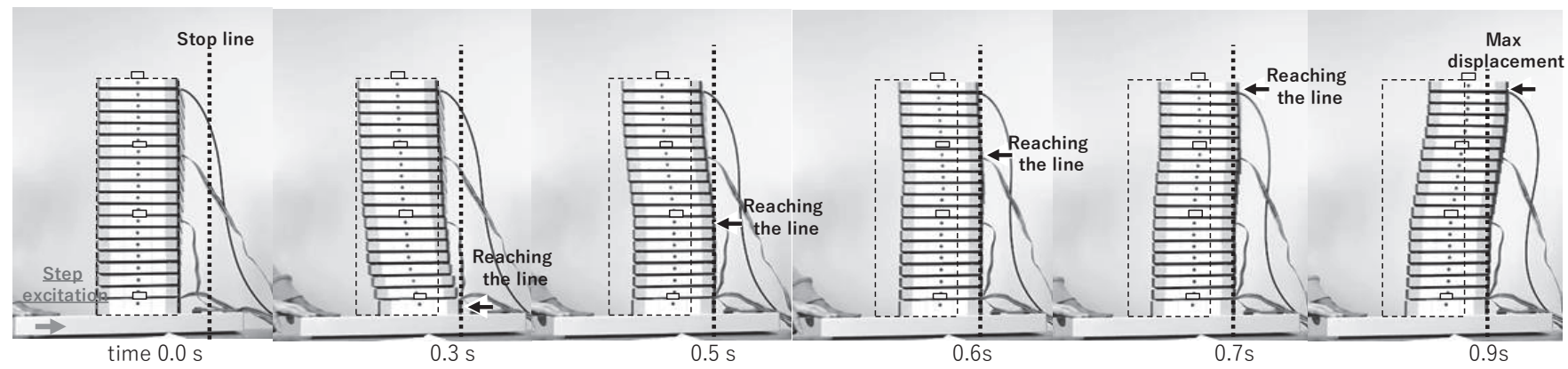

(e) Snapshot for step excitation at the bottom

Fig. 14 Vibration experiment to show wave propagation in multilayer model

有周期と減衰定数に代表される動特性の把握が重要である. 本章で は, 単層模型の動特性について, 自由振動実験により検討する.

$100 \times 100 \mathrm{~mm}$ ，厚み $6 \mathrm{~mm}$ の木板を用いた磁石の中心間距離 $L=70$ $\mathrm{mm}$ の Type A の試験体について検証する. ベアリングは直径 $D=$ $10 \mathrm{~mm}$ の鉄球とした。上側の板におもりを固定し, ベアリングより 上の質量を $3.06 \mathrm{~kg}$ とした.

Fig. 13(a)に, 自由振動実験に用いた模型と装置を示す. 下側の板 は机上に固定し，上側の板にくくりつけた紐により層間変位を $1 \mathrm{~cm}$ 程度あたえ, 紐を切ることにより自由振動を生じさせた。 その際,
上側の板に設置した MEMS 加速度計によりサンプリング周波数 200 $\mathrm{Hz}$ で計測を行った。

Fig. 13(b)に, 計測によって得られた加速度波形を 2 階積分し, 0.5 $\mathrm{Hz}$ 以上の高域通過フィルターを施した変位波形を示寸。また, Fig. 13(c)に 3 波区間の平均変位振幅に対寸る平均減衰定数を, Fig. 13(d) に 3 波区間の平均変位振幅に対する固有周期から算出した平均剛 性率を示す。また，同一模型に対する静的載荷実験の結果より求め た層間変位に対する割線剛性率を Fig. 13(d)に重ねて示している.

Fig. 13(c)より, 変位振幅約 $0.2 \mathrm{~cm}$ 以上では減衰定数は概ね一定で 
あり, 実際の建物・地盤とよく似た性質を示寸のに対して, 変位振 幅約 $0.2 \mathrm{~cm}$ 以下では振幅が減少するにつれて減衰定数が増大してい ることがわかる. 小振幅になるとベアリングの転がり抵抗等が相対 的に大きくなるものと考えられる. 減衰力の発生機構としては, 模 型の空気抵抗と鉄球に生じる誘導起電力（鉄球を貫く磁束の変化速 度に比例した起電力が発生し, 鉄球が電磁石となることにより, 運 動を妨げる方向に力が働く) が考えられる。

Fig. 13(d)より，岡性率は静的実験結果と概ね一致しており，層間 変位の増大とともに低下していることがわかる. また, 層間変位 0.1 $\sim 0.8 \mathrm{~mm}$ の範囲で剛性率は $230 \sim 260 \mathrm{~N} / \mathrm{m}$ の小さい変化であり, 復 元力特性がほぼ線形であることが動的な実験でも確認することがで きた.

\section{5. 多層模型のせん断波伝播}

本模型はば袮の機械的な要素により復元力が生じる模型と比較 して岡性が小さく, $1 \mathrm{~cm}$ 程度の層間変位まで線形性を保つ模型を実 現させることが可能である，そのため，多層模型を構築したとき， 目視でせん断波の伝播を確認することが可能である，これは，本模 型の大きな特徴の一つである. 本章では, 多層模型を加振したとき のせん断波の伝播についてスナップ写真で確認すると共に加速度計 測により伝播特性を検討する.

Fig. 14(a)に，加振実験に用いた多層模型を示す．180×180 mm，厚 み $7 \mathrm{~mm}$ の木板を用いた磁石の中心間距離 $L=150 \mathrm{~mm}$ の Type A の 19 層模型である. 直径 $10 \mathrm{~mm}$ の鉄球をベアリングとして用いた. 模型全体の高さは $534 \mathrm{~mm}$, 両面四隅に磁石を設置した一枚の木板 と 4 個の鉄球を合わせたものを 1 層相当と考えると, その質量は $0.24 \mathrm{~kg}$ である. この模型に対して, 頂部をハンマーで吒くことに よるインパルス加振と, 基礎を手動でスライドさせることによるス テップ加振の 2 種類の加振を行った. Fig. 14(a)に示寸通り, 模型内 の 4 か所に加速度計を設置してサンプリング周波数 $200 \mathrm{~Hz}$ で計測 し，同時に全体の動画撮影を行った。

Fig. 14(b)にインパルス加振の際の加速度波形を, Fig. 14(d)にスナ ップ写真を示す. また, Fig. 14(c)にステップ加振の際の加速度波形 を, Fig. 14(e)にスナップ写真を示す. なお, 計測された加速度波形 に対して $0.1 \mathrm{~Hz} \sim 10 \mathrm{~Hz}$ の帯域フィルターを施した.

Fig. 14(b) と (c) の最大加速度 (図中の三角印) の発生時刻を元に 層間変位が模型内を伝播する速度を算出すると（ステップ加振によ る各波形は高振動数の成分が励起されているため正側ピークが読み 取りずらいため, 負側のピークを用いた.), それぞれ $74.6 \mathrm{~cm} / \mathrm{s}$ と $83.3 \mathrm{~cm} / \mathrm{s}$ となる. これらの值をもとに, 大場の方法 ${ }^{12}$ による(5)式を 用いて単層の剛性率を求めると, それぞれ $197.4 \mathrm{~N} / \mathrm{m}$ と $246.4 \mathrm{~N} / \mathrm{m}$ と なる.

$$
V_{s}=l \sqrt{\frac{k}{m}}
$$

ここで, $m$ は 1 層の質量, $k$ は層剛性, $l$ は階高である. 本検討に おいては，全体的に短周期の振動が励起されていることもあり，加 速度波形によるせん断波速度の読夕取りの精度は必ずしも高くない， しかし, それをもとに推算された層剛性は, Fig. 13 (d) に示される 剛性率の変動範囲内にほぼ収まっている. 当該実験に用いた試験体 は, 本章での試験体とは寸法が異なるものの, 同じ厚さの木板と同
じ直径の鉄球を用いたものであり，層剛性は同じである。このこと から，多層構造の模型を伝播するせん断波の速度が，層ごとの動特 性と良い対応を示した。

\section{6. まとめ}

本論文では，永久磁石とボールベアリング，および木板またはア クリル板により構成される新しい振動論教育用のせん断振動模型を 開発した。本模型は安価で単純な構成であるうえ, 剛性・高さの調 整が容易に可能である. 加えて, 複数回利用しても劣化による剛性 低下等が起こらず，連続体を模した模型も作成することができる. これにより，既往の振動模型よりも多様な実験が可能な模型を実現 できた．本論文では，この模型の基本的な復元力特性と振動特性に ついて, 実験と解析により検討を行った。その結果について, 模型 の使用方法の観点から以下にまとめて述べる.

・ベアリングの大きさや磁石の配置, または磁石の数を変えること で剛性を調整することができる，特に，使用性の良さと線形性の 観点から，透磁率の高い鉄球をべアリングとして用いることが好 ましい.

・模型の減衰定数は振幅に依らず概ね一定であり実際の建物・地盤 と同様の傾向を示寸，しかし，小振幅の際はベアリングの転がり 抵抗の影響が相対的に増加するため減衰定数は大きくなる.

・高層建物やせん断土柱など多層の模型を構築することで, 目視に より模型内の波動伝播を観察することが可能である.

課題としては, 本模型はせん断振動を表現しているため, 高層建 物において生じる曲げ振動については表現できない. 今後，さらに 多様な建物・地盤の振動現象をより忠実に再現できる模型の開発を 進める予定である。

\section{謝辞}

有限会社トライデザインの松島憲司氏には，模型の製作にご助力 いただいた。また，応用地震計測株式会社の梶原透氏には，模型実 験に用いる計測装置の選定に際しご協力をいただいた．それぞれこ こに記し，謝意を表す。

\section{参考文献}

1) Ishikawa, T. : Class of Visual and Experimental for Motivational Education and Its Effect -Through the Lessons "-Principles of Structural Design- " at the Department of Housing and Architecture of the Japan Women's University-, AIJ Journal of Architectural Education, No. 9, pp. 31-36, 2009 石川孝重: 動機付け教育における視覚・体験型授業の実施とその効果, 建築教育研究論文報告集, No. 9, pp. 31-36, 2009

2) Yamagishi, K. : Trial of Motivational Education in First Semester of First-year Architectural Education -Outline of the Subject and Understanding of Structure Forms by a Paper craft-, Proceedings of Annual Conference of Japanese Society for Engineering Education, pp. 412-413, 2016 山岸邦彰: 建築系初年次前期教育における体感学習の試み, 工学教育研 究講演会講演論文集, pp. 412-413, 2016

3) Ichinose, T. : "Structural mechanics learned on the homepage", Gihodo Shuppan Co., Ltd., 2004

市之瀬敏勝 : ホームページで学ぶ構造力学, 技報堂出版, 2004

4) Hisagi, A., Ishikawa, T. : Development of a Self-Instructional E-larning System for Structural Mechanics Learning for Students Having Different Academic Abilities, AIJ Journal of Technology and Design, No.33, pp. 801$806,2010.6$

久木章江, 石川孝重: 基礎学力に差がある学生に対する構造力学学習の 
ための自学自習用 e-larning システムの開発, 日本建築学会技術報告集, No. 33, pp. 801-806, 2010.6

5) Fukuwa, N., Hara, T., Koide, E., Kurata, K., Tsuruta, Y. : Development of Vibration Experiment Education Materials to Promote Seismic Retrofit, Institute of Social Safety Science Journal, No. 7, pp. 23-34, 2005 福和伸夫, 原徹夫, 小出栄治, 倉田和己, 鶴田庸介 : 建物耐震化促進の ための振動実験教材の開発, 地域安全学会論文集, No. 7, pp. 23-34, 2005

6) Tagawa, H. : Promotion of Understanding of Building Frame Behavior Using Model Teaching Materials -Learning of Deformation, Buckling and Vibration of Frames-, Proceedings of Annual Conference of Japanese Society for Engineering Education, pp. 118-119, 2014

田川浩: 模型教材による建築骨組挙動の理解促進, 工学教育研究講演会 講演論文集, pp. 118-119, 2014

7) Tsujihara, O., Nakatani, Y., Yamamura, T. : Development of Portable Shaking Experiment, Transactions of the Japan Society of Civil Engineers, A1, pp. 1052-1060, 2014

辻原治, 中谷雄一, 山村猛 : 摇れに対する感覚的理解を支援する卓上振 動実験装置の開発，土木学会論文集 A1,pp. 1052-1060, 2014

8) Hanai, T., Ishii, W., Oshida, M., Murao H., Fukuwa, N. : Development of Note Shaker and Structural Models for Education, AIJ Journal of Technology and Design, No. 29, pp. 57-60, 2009.2

花井勉, 石井渉, 押田光弘, 村尾秀己, 福和伸夫 : 防災教材, 振動論教 材としての卓上 2 軸振動台とその模型の開発, 日本建築学会技術報告 集, No. 29, pp. 57-60, 2009.2

9) Ehara, N., Hirai, T., Fukuwa, N. : Development of Shear Oscillation Model Consisting of Magnets and Bearings for Education of Building Oscillation and Disaster Prevention, Summaries of Technical Papers of Annual Meeting, Architectural Institute of Japan, Structures-II, pp. 539-540, 2018.9 江原夏季, 平井敬, 福和伸夫 : 防災意識啓発及び振動論教育のための磁 石とベアリングを用いた剪断振動模型の開発, 日本建築学会大会学術 講演梗概集, B-II, pp. 539-540, 2018.9

10) Takahashi, N. : "Finite element method of magnetic engineering", Asakura Publishing Co., Ltd., 2013

高橋則雄 : 磁気工学の有限要素法, 朝倉書店, 2013

11) Murata Software Co., Ltd. HP : https://www.muratasoftware.com, accessed 2018.6.1

12) Ohba, S. : Evaluation of Structural Characteristics Based on the Velocity of Shear Wave Proportion in Buildings, Transactions of the Architectural Institute of Japan, No. 336, pp. 34-41, 1984.2

大場新太郎：建物内を伝播寸るせん断波速度による実在建物の構造特 性評価，日本建築学会論文報告集，第 336 号,pp. 34-41, 1984.2 


\title{
DEVELOPMENT OF SHEAR VIBRATION MODEL FOR EDUCATION USING PERMANENT MAGNETS AND BALL BEARINGS
}

\author{
Natsuki EHARA*1, Takashi HIRAI ${ }^{* 2}$ and Nobuo FUKUWA*3 \\ ${ }^{* 1}$ Grad. Student, Grad. School of Environmental Studies, Nagoya Univ. \\ *2 Assist. Prof., Grad. School of Environmental Studies, Nagoya Univ., Dr.Eng. \\ ${ }^{*}$ Prof., Disaster Mitigation Research Center, Nagoya Univ., Dr.Eng.
}

In the engineering education, effective experiments are necessary to understand the phenomena in addition to the theoretical learning. Also in the earthquake engineering, it is difficult to understand the theory of the soil and building vibration without appropriate experiments due to its complexity including the concept of time and frequency. Thus the effective teaching materials are necessary for the architectural education.

In this study, a new shear vibration model using permanent magnets and ball bearings was developed. The model is constructed by stacking the layer consisting of the wooden board and permanent magnets via ball bearings alternatively. The restoring force appears as the horizontal component of the magnetic interaction between the magnets lower and upper the bearings. The model has the stable performance and the long natural period enough to visually recognize comparing to existing materials. Additionally, the model has a lot of features: inexpensiveness of materials, variable natural period, visible shear wave propagation, multiple applications to represent soil and building structures, and so on.

In this paper, basic characteristics of the model are revealed by the theoretical analysis, the static and dynamic tests, and the vibration experiment. The results obtained are as follows:

1) The restoring force shows almost linear and nonlinear characteristics for small and large relative story displacement, respectively. This is the same tendency as the actual soil and buildings. The stiffness of the model varies with the size of the bearing, the arrangement of the magnets, or the number of the magnets. High toughness is realized by using iron ball bearings, since they are magnetized between the lower and upper magnets due to high magnetic permeability.

2) The damping ratio of the model is almost constant with respect to the displacement amplitude. This is the same tendency as the actual soil and buildings, similarly to the restoring force characteristics. However, the effect of rolling resistance of the bearings becomes dominant for small displacement amplitude, causing the increase of the damping ratio.

3) By constructing the multilayered model simulating the high-rise building or the shear soil column, it becomes possible to visually observe the shear wave propagation in the model. 